\title{
RESISTANCE OF CHINOOK SALMON (Oncorhynchus tschawytscha) FINGERLINGS EXPERIMENTALLY INFECTED WITH VIRAL HEMORRHAGIC SEPTICEMIA VIRUS
}

\author{
Wilma ORD \\ Institut National de la Recherche Agronomique \\ Laboratoire d'Ichtyopathologie \\ 78850 - THIVERVAL-GRIGNON
}

\begin{abstract}
Viral Hemorrhagic Septicemia (V.H.S.) is an infectious and contagious disease of rainbow trout (Salmo gairdneri) which produces muscular hemorrhagic lesions and necrosis of the hematopoetic system in infected fish. At least $40 \%$ of French commercial fish farms are affected by V.H.S. giving rise to very considerable annual economic losses.

Previous work has shown that brown trout (Salmo trutta) and Coho salmon (Oncorhynchus kisutch) are resistant to V.H.S. (de KINKELIN et al. 1974). To further our understanding of the susceptible host range of this disease the effect of exposure to V.H..S has been studied in chinook salmon compared with the susceptible species, the rainbow trout.

Rainbow trout and chinook salmon fingerlings (mean length $6 \mathrm{~cm}$ ) were divided into control and infected groups. The infected fish (10 rainbow trout, 7 chinook salmon) were injected intraperitoneally with $0.2 \mathrm{ml}$ STOKER medium containing $10^{4}$ plaque forming units (p.f.u.) of the virus of V.H.S, strain 07/71, serotype I (VESTERGARD-JORGENSEN 1972). The controls (8 rainbow trout, 6 chinook salmon) were injected with the same volume of virus free STOKER medium. Prior to injection, all fish were anaesthetized in a solution of $100 \mathrm{ppm}$ tricaine metanesulphate (MS-222).

To evaluate the course of the disease, two criteria were used: the incidence of mortality and a quantitative analysis of dead and sacrificed fish for the presence of virus. One fish from each infected group was sacrificed on days 2, 4 and 15 post injection. The spleen and kidney were carefully dissected and
\end{abstract}


weighed, ground in a mortar and diluted in EARLES medium. These viral extracts were then inoculated into Fathead Minnow (GRAVELL and MALSBERGER 1965) cell cultures according to previously described methods (de KINKELIN et SCHERRER 1970).

At the conclusion of the experiment, all fish were sacrificed and analysed for V.H.S. virus.

The water temperature of the fish tanks was maintained at $13 \pm 10 \mathrm{C}$.

Results of viral analyses and mortalities in these two species following exposure to V.H.S. are presented in table 1 . No mortality occurred and no virus was isolated in chinook salmon. In comparison, rainbow trout displayed heavy mortalities and virus was detected on days 2, 4, 5 and 8 in both sacrificed and dead trout. Highest viral yields occurred 4 to 5 days post infection. Viral analyses on fish sacrificed at the conclusion of the experiment were all negative.

These present findings suggest that chinook salmon fingerlings are refractory to V.H.S. This may be a common feature in the Oncorhynchus genus as the Coho salmon has also been shown to be resistant. However as susceptibility to virus could be age dependant, caution must be taken in extrapolating these results to cover other age groups of chinook salmon. Nethertheless prior to undertaking this experiment, the behaviour of chinook salmon of up to $15 \mathrm{~cm}$ length exposed to a natural infection of V.H.S. Was observed in the same fish farm which had been used to check Coho salmon susceptibility (de KINKELIN et al. 1974). No viral associated losses were recorded in ponds or cages placed downstream from infected rainbow trout ponds.

\section{SUMMARY}

This work compares the susceptibility of chinook salmon (Oncorhynchus tschawytscha) and rainbow trout (Salmo gairdneri) fingerlings injected with the virus of Viral Hemorrhagic Septicemia.

In chinook salmon, no deaths occurred and no virus could be isolated. In contrast, high viral titres were found in rainbow trout amongst which there was a heavy mortality.

\section{ACKNOWLEDGMENTS}

Appreciation is expressed to Dr. P. de KINKELIN for guidance and for kindly summarizing this article in French and to Mlle LE BERRE for helpful advice in cell culture.

\section{REFERENCES}

GRAVELL $M$. and MALSBERGER R. 1965. A permanent cell line from the fathead minnow (Pimephales promelas). Ann. .Y. Acad. Sci., 126, 555-565.

De KINKELIN P. et SCHERRER R. 1970. Le Virus d'Egtved : I - Stabilité, développement et structure du virus de la souche danoise $F_{1}$. Ann. Rech, veter. I (1) $17-30$.

De KINKELIN P., LE BERRE M. et MEURILLON A., 1974. Septicémie Hémorragique Virale: Démonstration de l'état réfractaire du Saumon Coho (Oncorhynchus kisutch) et de la truite Fario (Salmo trutta). Bull. Fran. Pisc., no 253, 166-176.

VESTERGARD-JORGENSEN P., 1972 a. Egtved virus : Antigenic variation in 76 virus isolates examined in neutralization tests and by means of the fluorescent antibody technique in Symposium of the Zoological Society of London: Diseases of fish, Academic Press, London and New York, 330-340. 


\title{
SEPTICEMIE HEMORRAGIQUE VIRALE : RESISTANCE DU SAUMON CHINOOK \\ (Oncorhynchus tschawytscha)
}

A L'INFECTION EXPERIMENTALE

\begin{abstract}
RESUME
Dans le cadre du développement d'un plan national de prophylaxie sanitaire, des recherches ont été entreprises pour éprouver la sensibilité des différentes espèces de salmonidés à l'infection par le virus de la Septicémie Hémorragique Virale (S.H.V.).

Le comportement du saumon chinook (Oncorhynchus tschawytscha) a été examiné et cet animal s'est révélé réfractaire à l'infection expérimentale réalisée par l'injection intrapéritonéale de $10^{4}$ unités formant plage (u.f.p.) par animal d'un poids moyen de $2 \mathrm{~g}$. Aucune mortalité n'est survenue chez les saumons et le virus n'a pas été isolé chez les animaux sacrifiés en fin d'expérience $(t$. I). Inversement les truites arc-en-ciel servant de témoins sensibles ont présenté une mortalité associée à l'isolement viral.

Le petit nombre des animaux d'expérience s'explique par le fait qu'un faible effectif venait d'être introduit en France, mais l'observation de ces animaux placés dans des conditions naturelles d'infection, comme au cours des essais antérieurs pratiqués avec le Coho (de KINKELIN. LE BERRE et MEURILLON 1974), a conduit au même résultat que l'inoculation du virus. Le saumon Chinook peut donc être considéré comme réfractaire à la S.H.V.
\end{abstract}




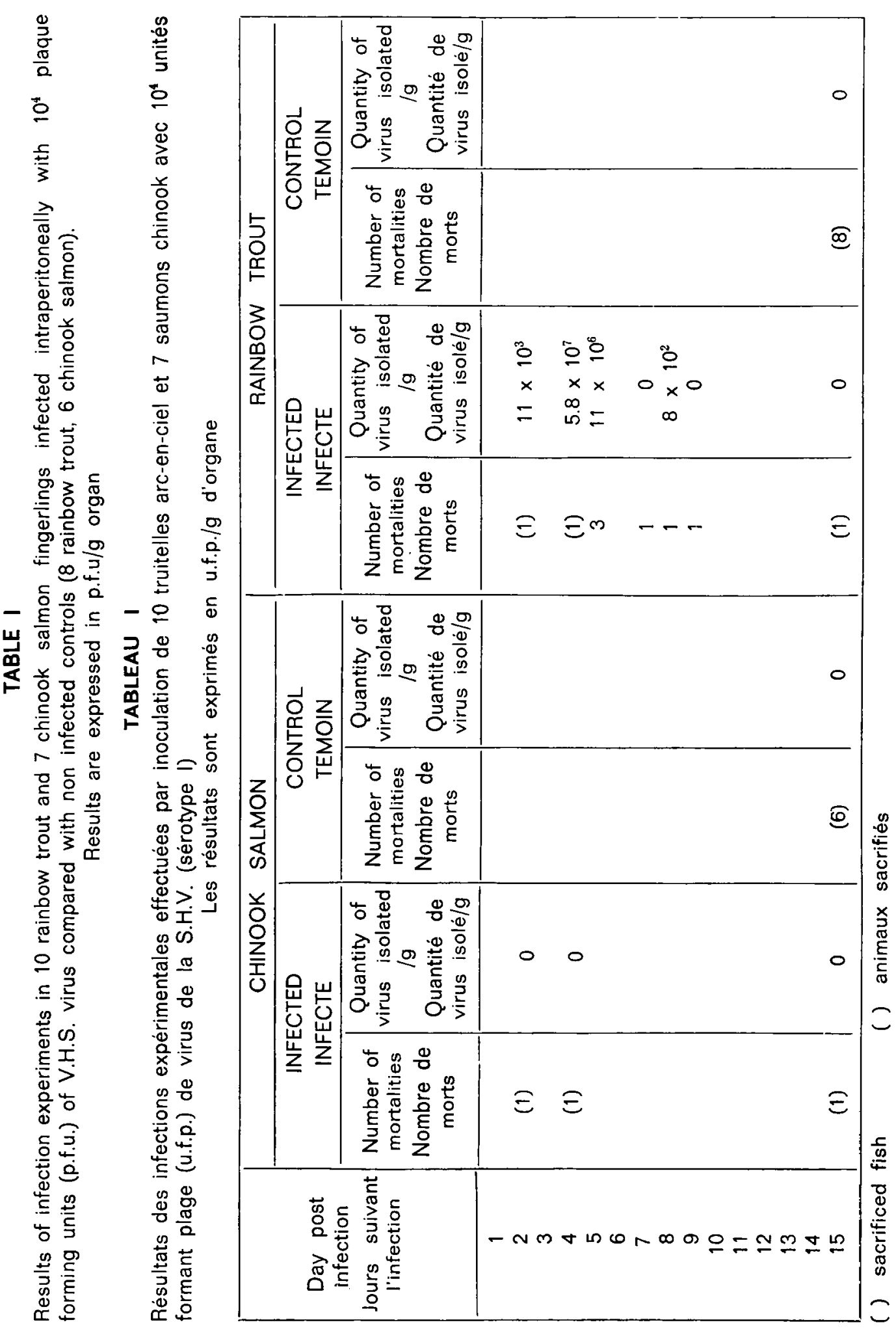

